This is an Accepted Manuscript of an article published by Taylor \& Francis in the British Journal for the History of Philosophy on 07 Nov 2016, available online:

http://dx.doi.org/10.1080/09608788.2016.1225565

\title{
Reversibility and chiasm: false equivalents? An alternative approach to understanding difference in Merleau-Ponty's late philosophy
}

\section{Fiona Hughes}

School of Philosophy and Art History, University of Essex, Wivenhoe Park, Colchester, UK

\begin{abstract}
The chiasm is usually considered the key notion for Merleau-Ponty's later philosophy. I argue against a common conclusion, namely that 'the chiasm' is equivalent to 'reversibility'. Even when the two terms are not taken as interchangeable, the precise nature of their relation has not been adequately established. Focusing exclusively on 'reversibility' has implications for a range of philosophical issues, including relations between self and other. The danger of substituting one term for the other is that existential relations are construed as inversions, rather than as genuine exchanges. I examine two trajectories that can be discovered in 'The Intertwining-The Chiasm'. The first is the inclusion of difference within a peculiar, extended sense of 'reversibility'. The second is the development of a plurality of expressions, among which 'reversibility' is necessary but not sufficient. I go on to argue that Merleau-Ponty secures difference within the chiasm by supplementing the notion of reversibility with 'imminence', the idea that something has not yet occurred. I also propose that the figure of a threshold illuminates how the chiasm operates as a transition where both joining and differentiation occur.
\end{abstract}

Keywords: Chiasm; reversibility; difference; imminence; threshold

\section{Introduction}

The chiasm is usually considered the key notion for Merleau-Ponty's later philosophy. ${ }^{1}$ For Merleau-Ponty, the chiasm expresses how, as embodied beings, our experience is characterized by relations, the elements of which mutually imply - yet are different from one another. For instance, if I see something tactile my senses overlap with one another, as when I see someone wearing a red woolly jumper sitting on a red plastic chair. ${ }^{2}$ The red of her jumper is different from that of the chair because of their tactile qualities. The jumper looks soft, the chair looks shiny, and these visible features are seen as tactile even though I am presently touching neither. One sense (seeing) implies another (touching or being aware of the potential for touching). I say that one quality 'implies' another and not that I 'infer' one from the other, because within perception I deduce neither from evidence nor through reasoning. An implication may or may not be logical, as I can imply something through a gesture or some other 'body language'. The sense in which I am using 'implication' in this paper is of something being necessarily involved with another within existential relations. ${ }^{3}$ The senses imply one another: I perceive a tactile quality as necessarily involved in what I see. This is the normal structure of sensory perception, for an experience of one sense in isolation arises only in exceptional cases - as, for instance, in sensory deprivation. But the redness of the jumper is also different from - that is, not reducible to - its woolly quality, otherwise I could not perceive the chair as red. Such differences within perception are irreducible yet not absolute, because they necessarily arise within existential relations.

The chiasm as a model for existential relations has ramifications for the philosophical examination not only of sensory perception, including proprioception, but also of the relation between perception and ideas (VI 149ff; 195ff). ${ }^{4}$ The notion of the chiasm allows MerleauPonty to insist on the mutual implications of sensory perception and ideal objects, while not 
reducing the latter to an abstraction from the former, as would empiricism. ${ }^{5}$ In the next section I illustrate this with the example of a musical idea.

At all levels, a chiasm operates as a dynamic relation between elements that never quite coincide and this captures the structure of existential relations that define embodied human experience. These include our relations to others, self-identity in relation to others and the self as relating to itself over past, present and future. In all of these cases, the philosophical importance of the chiasm is to establish that such relations cannot be simply accounted for in terms of identity or opposition and operate through both mutual implication and difference. Thus the specific force with which Merleau-Ponty takes up the classic philosophical topos of identity and difference is in respect of an embodied subjectivity existentially implicated with others and the world. ${ }^{6}$

In this paper I take issue with the strategy of treating the chiasm as equivalent to 'reversibility', an approach that has been adopted by many critics and defenders of MerleauPonty alike. Focussing exclusively on 'reversibility' has encouraged a misreading of the chiasm, namely as the occurrence of a switch or mere inversion from one perspective to another. Crucially, for critics of Merleau-Ponty - principally Levinas and Irigaray reversibility does not amount to a genuine exchange and is, rather, the replacement of one thing with an indifferent other (Levinas, 'Meaning and Sense'; 'Le signification et le sens'; Irigaray, An Ethics of Sexual Difference; Éthique de la différence sexuelle).

We will see, however, that Merleau-Ponty's own thinking leads to the identification of chiasm with reversibility. Crucially, he developed a peculiar sense of 'reversibility' that includes difference. I will argue that this new usage taken in isolation would put the differential status of the chiasm at risk. However, I also argue that a potential alternative strategy arises through his elaboration of a plurality of terms, among which 'reversibility' is one. I highlight another of these terms, namely, 'imminence' - the idea that something is anticipated but has not yet occurred. I argue that 'reversibility' is most successfully deployed when it is treated as part of - not as identical to - the full meaning of the 'chiasm'. I will argue that the meaning of the chiasm is resistant to economic expression and requires the elaboration of a series of inter-related terms. In conclusion, I propose the model of a threshold as a perspective that illuminates the general structure of the chiasm and, in particular, its status as a transition, which - as imminent - both joins and divides.

My account is critical in that, when necessary, I mobilize one element of Merleau-Ponty's thinking against another, as well as evaluating the conditions for its success. By doing so I will show that it is possible to distinguish two terms often taken as equivalent. Through emphasizing the importance of imminence, I will show that within Merleau-Ponty's late writings there is a genuine role for difference, even though it is not equivalent to the absolute difference proposed by his critics.

\section{An initial view of the chiasm and of reversibility}

Although the term 'chiasm' (chiasme) principally arises in the final chapter of The Visible and the Invisible, the expression encapsulates the overarching idea of all Merleau-Ponty's later work, namely, his rejection of construing the elements of experience as either identical or as standing in opposition to one another. ${ }^{7}$ One expression of this position is to be found in his rebuttal (VI 130; 172). The general structure of the chiasm entailing themutual implication of its elements combined with their difference makes possible an alternative form of reflection that is both distinct from its object and implicated in it. The chiasm is characteristic of embodied existential relations, as the structure of 'flesh' (chair) that encompasses not only human bodies, but also animals, things and, ultimately, the world. ${ }^{8}$ The notion of flesh is not simply equivalent to embodiment (incarnation): while existential relations are always founded 
in the body, the life of the flesh is capable of transfiguring - while still preserving - its corporeal origin. ${ }^{9}$

The title of the final chapter of The Visible and the Invisible - 'The Intertwining - The Chiasm' (L'entrelacs-le chiasme) - suggests that these terms are equivalent. While Merleau-Ponty gives no explanation within this chapter of 'intertwining', the term implicitly suggests how two or more things are inter-related despite their difference. Only things that are in some respect different can be intertwined, otherwise they would be simply one and the same.

In the interest of expressing the structure of the chiasm, Merleau-Ponty deploys a series of images. While it may be objected that in so doing he falls into merely verbal considerations, in his view, philosophical thinking cannot be detached from the language deployed in its expression (Merleau-Ponty, Phenomenology of Perception, 206;Phénoménologie de la Perception, 206). In The Visible and the Invisible finding the right medium for the expression of ideas becomes an essential part of philosophical work. An analysis of such expressions is thus important for an adequate understanding of his position.

One of the most suggestive of these images arises in Eye and Mind where, drawing on Paul Klee, he writes: 'In a forest, I have felt many times over that it was not I who looked at the forest. Some days I felt that the trees were looking at me, were speaking to me ...' (MerleauPonty, Primacy of Perception, 167; L'oeil et l'esprit, 31). ${ }^{10}$ This is an image of our corporeal intertwinement with the world, of which the artist is exemplary. The painter's body operates through an 'intertwining' (entrelacs) of vision and movement (Merleau- Ponty, Primacy of Perception, 124; L'oeil et l'esprit, 17). 'Intertwining' is the alternative term for the chiasm in the title of the final chapter of The Visible and the Invisible, as we have seen. As Johnson remarks, this thought had already been introduced in the earlier essay on Cézanne: 'The landscape thinks itself in me and I am its consciousness' (Merleau-Ponty, The MerleauPonty Aesthetics Reader, 44). ${ }^{11}$ We can find another expression of this idea as early as Phenomenology of Perception, where, quoting Valéry, he writes that the blue of the sky 'thinks itself within me' (Merleau-Ponty, Phenomenology of Perception, 249;

Phénoménologie de la Perception, 248). There is no mention of chiasm - or indeed of reversibility - in either of these texts, but the idea of intertwining is already formed, even though it does not yet have a name. All these examples suggest an exchange between activity and passivity, which though central to the chiasm does not exhaust its most fundamental meaning, which is of mutual implication over difference.

An explicit example of the chiasm arises in the final chapter of The Visible and the Invisible where Merleau-Ponty discusses one's right hand touching one's left hand, which is touching an object. There is 'a veritable touching of the touch, when my right hand touches my left hand while it feels [palper] things' (VI 133-4; 176). ${ }^{12}$ This example is important not simply because I can experience my hand as either active or passive, but because my touchingtouched hand operates at the limit between activity and passivity. My hand crossing over between activity and passivity is an expression of my body as affording an on-going series of transitions between the positions of agent and patient, but also of interchanges between the tactile and the visual. I see my hand both touching and being touched and this makes an essential contribution, according to Merleau-Ponty, within my tactile awareness. Thus the example of my hand as touching-touched combines several levels at which the chiasm operates: at the boundary between activity and passivity; at a boundary within a sense (touching and touched); and at a boundary between senses (touch and sight). Moreover the example possibly suggests a further boundary, namely, between thinking and perception, for this 'crisscrossing' is only possible 'if my hand, while it is felt from within, is also accessible from without' (VI 133; 176). This feeling of an interior world may be Merleau-Ponty's first intimation of a world of thinking and of ideas. Finally, my hand touching and being touched implies that I experience myself almost as another self and is suggestive of what it is to feel 
the hand of another. Merleau-Ponty takes this up later, saying that the handshake opens us up to other bodies $(142,187)$. In these various ways, the touching-touched hand reveals a number of forms of the chiasm's primary structure, namely, the combination of mutual implication with difference.

When Merleau-Ponty explicitly takes up the chiasm between flesh and idea - which he says is 'the most difficult point' - he turns to Proust, for whom a little musical phrase expresses Charles Swann's idea of his being in love with Odette (VI 149; 195-6). The meaning of this musical idea arises in the crossing over between what Merleau-Ponty calls 'visibility' and 'invisibility', by which he means the relation between the expression of the idea in a particular performance and the idea's exceeding of any particular expression. Proust describes a variety of performances of the 'little phrase' and in each case the music 'belonging to another world' is 'so near and yet so infinitely remote' (Proust, In search of lost time I, 262; À la recherche du temps perdu I, 215). But this is not to say that the idea would be 'better known to us if we had no body and no sensibility', for these are the conditions of our access to the idea (VI 150; 196). The idea appears in perception as not wholly given, with the consequence that it can only be grasped at the limits of - and yet not beyond perception.

For Merleau-Ponty, the musical idea is not simply a psychological entity nor is it wholly independent of experience: what transcends any particular experience must nonetheless be performed. One may prefer Edwin Fischer's or Angela Hewitt's performance of Bach's The Well Tempered Clavier. ${ }^{13}$ Meanwhile, Glenn Gould's performance may be viewed as a vibrant embodiment of the spirit of the music or his audible utterances considered a distraction from it. ${ }^{14}$ Aesthetic evaluations of these performances are generally not directed to technical competency - for each of them fulfils that initial condition - and address, rather, whether the performance 'does justice' to the music. It follows from Merleau-Ponty's account of the musical idea that the essence of a musical work is not fully captured in any performance, although it may be more successfully expressed in some rather than others. Merleau-Ponty often refers to 'reversibility' in his accounts of the chiasm and it is tempting to conclude that the second term is explained by the first. Indeed, at times he uses the terms equivalently and on one occasion refers to reversibility as 'ultimate truth' (vérité ultime), where the truth expressed seems to be that of the chiasm (VI 155; 204).

Whatever the verdict on the relation between chiasm and reversibility, we should not conflate the latter with an achieved reversal. While reversal (retournement or renversement) plays a role in the account of the chiasm, the mere occurrence of reversals, switches or changes of perspective is not Merleau- Ponty's principal concern: rather, he intends to establish that all of the elements of experience stand in a relation of possible reversal to one another.

'Reversibility' certainly captures a crucial element of the significance of the images of the chiasm. In each case, one position is exchangeable for another. This could seem to invite the conclusion that there is no genuine exchange and that the two elements are merely indifferently substituted for one another. ${ }^{15}$ As an illustration of this temptation, we might consider that reversibilité in French refers to, for instance, fabric that can be reversed or switched from one side to another, as in a reversible raincoat. Prima facie, the outside and inside are unproblematically substitutable for one another. This, however, is neither the sense of Merleau-Ponty's chiasm, nor indeed his use of 'reversibility'. In order to grasp his use of both terms we need to go beyond not only any actual reversal, but also beyond the idea of a possible switching from one position to another. In an experience of a chiasm, I am aware of one element in an uncanny relation to the other - their continuity and their difference - as in the examples of the touching-touched hand and the musical idea. Moreover, the sense in which Merleau-Ponty uses 'reversibility' implies some relation to difference, as I shall argue. 
A reason - often remarked on - for treating 'reversibility' as substitutable for 'chiasm' is that in rhetoric 'chiasmus' refers to a figure of speech in which words, grammatical constructions or concepts are repeated in reverse order. An elegant example is: 'You forget what you want to remember, and you remember what you want to forget' (Cormac McCarthy, The Road). The word 'chiasmus' is derived from the Greek letter X (chi), a sign considered to be a visual presentation of reversal or inversion.

However, Merleau-Ponty's inauguration of a philosophical sense for 'chiasm' is only analogous to and not identical with its rhetorical sense. My contention is that even if the rhetorical use can be fully captured as 'reversibility' - something I will leave rhetoricians to determine - the philosophical use inaugurated by Merleau-Ponty cannot. ${ }^{16}$

The general structure I am proposing is not sufficient for accounts of specific chiastic forms, for instance, the relation between self and other. Nonetheless, determining the general structure of the chiasm establishes the combination of mutual implication with difference in respect of embodied existence that is the necessary condition of any particular chiasm.

\section{The substitution strategy and its implications for difference}

Merleau-Ponty's ideas of 'reversibility' and 'chiasm' are sometimes explicitly presented as synonymous, often they are used as if they were equivalent and never, as far as I can see, have they been systematically distinguished from one another. ${ }^{17}$ In this section I will discuss how the supposed equivalence of these terms - which I will call the Substitution Strategy - is crucial for the interpretations not only of critics of Merleau-Ponty such as Levinas and Irigaray, but also for supporters, principally Dillon.

Treating 'reversibility' as equivalent to 'chiasm' has led to considerable criticism of MerleauPonty. While the recurrent critique is that reversibility results in an inattention to the difference between self and others, a series of interconnected repressions of difference could arise: between self and world, as well as within the self, to name but two. For Levinas and Irigaray, two principal critics of Merleau-Ponty's late philosophy, Merleau-Ponty's chiasm cannot account for the ethical difference between self and other, because it is equivalent to reversibility.

In 'Meaning and Sense' Levinas admits a debt to Merleau-Ponty for having established the importance of embodied existence in the world (Levinas, 'Meaning and Sense', 80-1; 'Le signification et le sens', 130-1). However, Levinas goes on to reject what he holds to be Merleau-Ponty's conclusion, namely, that the ideal world ultimately is derived from the embodied world (Levinas, 'Meaning and Sense', 83-4; 'Le signification et le sens', 133-4). ${ }^{18}$ For Levinas, Merleau-Ponty's rejection of 'Platonism' has an ethical implication, namely, the reduction of the 'absolute difference' of the other to the merely mediated or contextual (Levinas, 'Meaning and Sense', 83-6; 'Le signification et le sens', 133-5). Levinas concedes that for Merleau-Ponty we are faced with an other, but the other person arises within a situation and so does not achieve the status of the absolute ethical other. It would be misleading to suggest that any form of reversal is negative for Levinas who does not explicitly attack the idea of reversibility. ${ }^{19}$ However, there are good grounds for concluding that Levinas rejects reversibility at a number of levels. He is opposed to cultural reversibility where no cultural perspective would have priority over any other: to deny the priority of one standpoint over another is to render taking an ethical position impossible (Levinas, 'Meaning and Sense', 83; 'Le signification et le sens', 133). ${ }^{20} \mathrm{He}$ is principally opposed to reversibility understood as the substitution of self for other, as we have seen. Both of these positions, in Levinas' view operative in Merleau-Ponty's philosophy, imply a reversal that amounts to reciprocity, by which Levinas means a suppression of difference (Levinas, 'Meaning and Sense', 92; 'Le signification et le sens', 141). ${ }^{21}$ Perhaps the most explicit evidence of Levinas' rejection of reversibility in 'Meaning and Sense' is his characterization of the 
absolute as 'irreversibility' (Levinas, 'Meaning and Sense', 103-5; 'Le signification et le sens', 152-4). It is clear that, for Levinas, Merleau-Ponty fails to achieve an ethical position because he rejects irreversibility in favour of the chiasm, choosing a 'sideby- sideness' and a 'belongingness' over commitment to meaning in itself and the love of truth (Levinas, 'Meaning and Sense', 83-4; 'Le signification et le sens', 133-4). I agree with Levinas that ethical relations require recognition of genuine difference. However, Merleau-Ponty proposes an account of difference as irreducible and not absolute, because of the primacy of existential relations.

Irigaray's critique is explicitly addressed to the chiasm as equivalent to reversibility, thus rendering the other invisible by treating her as the same (Irigaray, An Ethics of Sexual Difference, 181-184; Éthique de la différence sexuelle, 168-171). Reversibility entails sameness and, she argues, must be interrupted if difference is to be possible (Irigaray, An Ethics of Sexual Difference, 180; Éthique de la différence sexuelle, 168). By this she means, I believe, that the elements in a relation must be marked by a gap in order to avoid one term simply being projected onto another. Irigaray - like Levinas - holds that difference can only be secured if it is recognized as absolute. Her alternative version of the chiasm secures difference by founding it in sexual difference, which is the impossibility of a man taking the place of a woman and vice versa (Irigaray, An Ethics of Sexual Difference, 13; Éthique de la différence sexuelle, 19-20). Merleau-Ponty, she argues, fails to address the sexual difference between self and other and proceeds as if subjectivity were unsexed - the implied model for all subjects being male. It is because, in her view, Merleau-Ponty omits to address what she calls 'the interval' existing between man and woman that his chiasm cannot address the other (Irigaray, An Ethics of Sexual Difference, 183; Éthique de la différence sexuelle, 170). Irigaray differs from Levinas and concurs with Merleau-Ponty that the transcendence of the other must be established within the world of perception: this is what she calls the 'sensible transcendental' (Irigaray, An Ethics of Sexual Difference, 115; Éthique de la différence sexuelle, 111). Irigaray thus takes issue with Merleau-Ponty specifically on his failure to recognize that ethical difference is absolute and sexual and this criticism is based on her view that his version of the chiasm is equivalent to reversibility. I agree with Irigaray that Merleau-Ponty pays inadequate attention to sexual difference. However, I will show that interruption plays an important role in his account of the chiasm.

Turning now to those supporters of Merleau-Ponty who, in my terms, are also representative of the Substitution Strategy, Dillon stands out as the initiator of 'The Reversibility Thesis', according to which reversibility is the central thought of the later Merleau-Ponty (Dillon, 'Merleau-Ponty and the Reversibility Thesis'; Merleau-Ponty's Ontology, 153-176; see Hass, 'Sense and Alterity', 101-102). The primary aim of Dillon and his followers is to insist that reversibility is the fundamental topic rather than to establish the equivalence of 'reversibility' and 'chiasm'. Nonetheless, for these interpreters 'reversibility' fully captures the content of the 'chiasm'.

Cognisant of the criticisms of Levinas, Irigaray and others, proponents of the Reversibility Thesis insist that the notion of reversibility entails difference and thus is able to account for ethical difference. Lawrence Hass, who follows Dillon in defending Merleau-Ponty by insisting on the centrality of reversibility, outlines three ways in which this notion has been seen as giving rise to problems. Firstly, it has been considered obscure; secondly, it begs the question of other minds; thirdly, it eliminates the difference between oneself and others (Hass, 'Sense and Alterity', 92) ${ }^{22}$ In the face of these distinguishable but inter-related criticisms, Hass insists that difference is a necessary component of the notion of reversibility, which is the 'master term' that includes all others ('Sense and Alterity', 100;Merleau-Ponty's Philosophy, 131-2). Dillon repeatedly claims that reversibility entails 'identity-and-difference' or 'identity-withindifference'. (Merleau-Ponty's Ontology, 157, 159, 160, 166). In particular, he argues that reversibility operates through asymmetry and ambiguity (Merleau-Ponty's Ontology, 158-9, 160-1, 190). By defining reversibility so as to include difference, it is clear 
that - for Hass and Dillon - 'reversibility' is sufficient for the expression of the complex idea of chiasm.

Nonetheless, within the paradigm where reversibility includes difference, insufficient account is given of the relations between identity and difference and, in particular, of transitions between them. We understand that reversibility is supposed to imply both identity and difference, but there is insufficient explanation of how this is possible. At one stage Dillon explicitly addresses the transition between difference and identity suggesting that the Reversibility Thesis offers a solution to the threat of conflict between perspectives. Dillon's proposal is that it is possible to exchange positions (in our way of thinking) with someone else through communication. It is 'guaranteed in principle although not always easy to carry out, that an initial dissonance move in the direction of an ideal harmony by reversing positions' (Merleau-Ponty's Ontology, 170). The problem with this account is that the dynamic of exchange between interlocutors is not directly addressed. How exactly is difference (or asymmetry) preserved within the ideal harmony? Without such an account, the danger is that the 'ideal harmony' turns out to amount to the success of one person's perspective over the other's or to the participants agreeing to agree at the lowest common denominator. While the relation between difference and identity - and between self and other - is now explicitly addressed, this solution risks giving priority to agreement over disagreement by resolving difference into a harmonious whole. On this reading, the critical objection that Merleau-Ponty reduces difference to the same re-emerges at another level. In the next section, however, we will see that the Reversibility Thesis is grounded in MerleauPonty's own account. The problem I have identified - of the transition between identity and difference - arises from Merleau-Ponty's tendency to treat 'reversibility' as equivalent to the chiasm.

\section{Merleau-Ponty's two trajectories: (i) reversibility at the second degree (ii) a plurality of expressions for the chiasm}

In this section I will examine the new meaning Merleau-Ponty develops for 'reversibility' and the way in which it incorporates difference. I will argue that there are grounds - both internal and external to Merleau-Ponty's thought - for criticizing this approach. Finally, I will argue that he opened up an alternative trajectory for the expression of the chiasm.

Throughout the text of 'The Intertwining' as well as in Merleau-Ponty's working notes, we find evidence for regarding the chiasm and reversibility as equivalent. In addition to the claim that reversibility is 'ultimate truth', it is also 'a fundamental phenomenon' (VI 155; 203) and 'defines flesh' (VI 144; 189). In a famous working note from November 1960 entitled 'Chiasm - Reversibility' Merleau-Ponty claims that reversibility is the sole way of securing the 'passage from the "For Itself" to the For the Other' (VI 263; 317). In another note from the same month we read: 'The chiasm, reversibility, is the idea that every perception is doubled with a counter-perception ...' (VI 264-5; 318). These comments forcefully suggest that the relation between 'reversibility' and chiasm is one of equivalence. Moreover, a note from December 1960 states that: " ...reversibility is not an actual identity of the touching and the touched. It is their identity by principle (always abortive [manqué]) ...' (VI 272; 325-6). This suggests not so much resolution in an ideal harmony, as an on-going struggle between identity and difference. However, in all other respects, at this stage at least, the Reversibility Thesis is on firm ground for there appears to be a reply to Levinas and Irigaray, namely that 'reversibility' is equivalent to the chiasm and yet entails difference. This is only possible because the use of 'reversibility' within The Visible and the Invisible is not identical to its everyday usage. Nonetheless, I will argue that Merleau-Ponty's sense of 'reversibility' cannot be completely detached from its 'normal' use.

Saint Aubert (Être et Chair, 251-71) makes a compelling and sophisticated case for the equivalence of chiasm and reversibility, based on a close reading of published and 
unpublished texts. He argues that Merleau-Ponty develops a series of 'figures of thought', entailing 'terminological adaptation' of existing uses (Saint Aubert, Du Lien des Êtres aux Éléments de l'Être, 61-2). In an unpublished manuscript from April or May 1960, 'reversibility', one of these figures, takes on the sense of a 'sublimation' operating at the 'second degree' (Saint Aubert, Être et Chair, 263).

Merleau-Ponty used the term 'reversibility' in this special sense almost exclusively during the month of November 1960 at which time he was writing a draft of what would be published posthumously under the title The Visible and the Invisible (Saint Aubert, Être et Chair, 251). Earlier in 1960 as well as throughout 1959 Merleau-Ponty took issue with Piaget for whom perception is irreversible and thinking is reversible, For Piaget, this is because perception is passive, insofar as the subject merges with the external world, while thinking is active and operates on the external world through abstraction (Saint Aubert, Être et Chair, 253-7). Merleau-Ponty insists that not only perception but also thought is irreversible. This is particularly the case for expression, which because of its temporal, intentional and practical nature is asymmetric (Saint Aubert, Être et Chair, 262-3). In other words, expression is not purely active, because it arises within what I am calling existential relations. Merleau-Ponty, thus, defended irreversibility - as equivalent to asymmetry - against reversibility - as equivalent to symmetry (Saint Aubert, Être et Chair, 263).

Yet in the same manuscript Merleau-Ponty defended the new sense of 'reversibility' at the second degree. Saint Aubert shows us - through meticulous analyses - that this expresses, in effect, a reflection on the dialectic between reversibility and irreversibility in their Piagetian senses (Saint Aubert, Être et Chair, 263-4). ${ }^{23}$ 'Reversibility' used in this peculiar way Reversibility* for brevity - is a technical term incorporating difference, as well as a range of features of the chiasm I will discuss in the next section. As Reversibility* allegedly captures the full chiastic structure of the touching-touched hand and of the musical idea, must we not conclude that the two terms are equivalent?

The problem, however, is whether Reversibility* is capable of adequately expressing both sides of the complex structure of the chiasm, without suggesting, unintentionally, that irreversibility is resolved in an 'ideal harmony'. While this was clearly not Merleau-Ponty's intention, the problem is one of effective expression. The expressive capacity of Reversibility* is compromised by the excessive inclusiveness of the meaning claimed for it. As a result, the role of difference within the chiasm - which depends on the latter's displaying asymmetry as well as symmetry - is at risk.

I am not criticizing Merleau-Ponty for extending the ordinary use of terms, a tactic that allows writers to challenge readers through choice of expression, as well as through argument. However, seeking to include within a new usage a seemingly limitless range of characteristics - and, in particular, going so far as to co-opt the opposite of the ordinary meaning - severely tests effective expression. The chiasm is peculiarly dependent on its mode of expression on account of the irreducibly elusive character of its meaning, which can be brought to greater clarity but never finally pinned down. Reversibility* suppresses rather than reveals the work required for the expression of the meaning of the chiasm.

Additionally, there is evidence that Merleau-Ponty disapproved of simply abandoning everyday linguistic usage. Although he is committed to creatively reinterpreting the ordinary sense of words, some retention of their common currency is required even - perhaps particularly - when terms are used against the grain.

But the moment people begin to reflect upon language instead of living it, they cannot see how language can have such power. After all, we understand what is said to us because we know in advance the meaning of the words spoken to us.

(Merleau-Ponty, The Prose of the World, 8; La Prose du Monde, 14) 
We know in advance the meaning of words because they are already in use. Language has power because we do not simply invent it through our reflections on it: we have to work with what is given to us within everyday expressions. This shows that for Merleau-Ponty a technical or creative use of a term should stand in some continuity with its 'given' sense, even when passing beyond it. If we now apply this principle to Reversibility*, we find that it should operate as a form of reflection on existing uses, retaining within it a sense of what has been transfigured. Thus the 'ordinary' sense of 'reversibility' would still be at work within - even though creatively reinterpreted by - Reversibility*. I am persuaded that MerleauPonty never gave up his commitment to working with 'the confusions' of ordinary language and I will argue that there is evidence for this commitment in the alternative trajectory he opens up. ${ }^{24}$ The question then arises as to whether Reversibility* is capable of effectively expressing all the senses deposited in it, when it has been stretched so far from everyday language.

Let us now consider the particular task of expressing the role difference plays in the chiasm. Reversibility* secures difference by definition. This is made possible by including the condition of difference - asymmetry - within a new and entirely technical sense of 'reversibility'. Such a 'Pickwickian' use of the term would be safe from the criticism that it omitted difference only because it operated purely within its own logic even so far as to incorporate its opposite through the invention of a new rule or language game. Creativity in language, as elsewhere, must work on something and the material for new uses is the range of meanings already in use. This is not to say that the old will wholly determine the new sense. However, there must be some trace of the old sense in the new if the latter is successfully to carry out its mission of expression. If redefinition were the only strategy for the expression of the chiasm Merleau-Ponty would be in danger of losing sight of the necessary relation between his neologism and everyday language.

It is, I think, because Merleau-Ponty is temperamentally opposed to philosophizing through definition - even creatively - that at the same time as Reversibility* we can discover within his text a second trajectory, namely, the elaboration of a plurality of expressions that severally add to our understanding of what he means by 'chiasm'. He remarks on two occasions that 'flesh' has no name in philosophy. On the first occasion it lacks a name in 'traditional' philosophy; he goes on to say that it lacks a name in any philosophy (VI 139; $183,147 ; 193)$. I suggest there is a progression in these statements. The second claim is that even in Merleau-Ponty's own philosophy there is no name that wholly expresses the elusive sense of 'la chair' or 'flesh'.25 This is because the philosophical sense of 'flesh' he is elaborating is impossible to determine by any new name or neologism. Even though these statements refer to flesh and not to chiasm, they are relevant for the present discussion. Chiasm is the structure of flesh, by which I mean that Merleau-Ponty's philosophical notion of the chiasm refers to nothing other than the organization of flesh. ${ }^{26}$ Even though it is conceivable that the phenomenon is more elusive than its structure, it is at least a plausible conjecture that if flesh has no name in any philosophy, the meaning of the chiasm will also be difficult to name or express. We can find support for this conjecture in the second trajectory of his account, namely, the expression of the chiasm as a work in progress requiring a plurality of expressions. Through this approach, Merleau-Ponty offers further clarification of the sense of the chiasm, while refusing to provide a definition of - or name for - what he is nonetheless working to bring to greater clarity.

The chiasm as a crossing - or, better, a series of crossings - over difference, defeats easy or automatic expression. Reversibility is no doubt meant to overcome this shortcoming by incorporating multiple and even opposed senses within it. But, taken alone, a neologism would undermine the task of expression. As we have seen, Merleau-Ponty expresses the chiasm of 'flesh' through a series of images - for instance, the blue of the sky thinking itself in me - but now we will see he also develops a series of expressive terms, one of which I will examine in detail in the next section. While all of these terms could simply be regarded 
as sublimations within Reversibility*, in the next section I will argue that a crisis emerges within the overly inclusive new language game.

\section{Imminence: securing difference within the chiasm}

In this section I argue that the introduction of the notion of imminence leads to a crisis in the strategy of Reversibility*, opening up as an alternative the elaboration of a plurality of expressions for the chiasm. The broader picture is that throughout 'The Intertwining' Merleau-Ponty introduces a series of distinctively nuanced expressions for the chiasm. It would be impossible to adequately account for - or even name - all these expressions here. I will concentrate on imminence, because it is both critical for the meaning of the chiasm and only very uneasily included within Reversibility*. I will show how imminence highlights the turning point between reversibility and irreversibility keeping open the dialectic between them and bringing to the fore the elusive character of the chiasm.

Something that is 'imminent' is about to happen but has not yet happened. Merleau-Ponty introduces the idea of imminence in his most developed image of the chiasm, namely, of my two hands touching one another. This exchange qualifies as 'a reversibility [reversibilité] always imminent' (VI 147- 8; 194). Insofar as the chiasm is characterized by imminence, there is a gap between what is anticipated and its occurrence. This may not be obvious once 'normal service' is resumed and what was imminent becomes a fact. Nonetheless, there will have been a gap in transmission even though we did not - or we no longer - focus on it.

My experience of my right hand as active, that is, touching something, is imminent to my experience of the same hand as passive insofar as it is touched by my other hand. These experiences are neither distinct nor detached: in the touching-touched crossing over from one to the other is anticipated. I cannot experience my hand as active coinciding with the same hand as passive (VI 147-8; 194). Yet, the experience of my hand as active retains an imprint of my experience of it as passive. The experiences never entirely overlap, but no more can they be entirely disentangled from one another. In the touching-touched as a crossing over between activity and passivity I am ambiguously aware of two different roles played by my hand despite their being aspects of one and the same body (VI 148; 194). The two perspectives on my hand, thus, do not merely constitute a 'perspective shift', that is, an alternation between perspectives, for they continuously interfere with one another within an imminent unity. Holding onto this uncanny feeling is, however, difficult. It is easier to bracket the feeling of the 'touching-touched' and experience my hand as a passive quasi-object ' $\mathrm{l}$ ' want to scratch or, alternatively, my hand is an instrument of my agency when I pick something up.

It is possible - perhaps even natural - to read Merleau-Ponty's statement that reversibility is always imminent as identifying the chiasm with 'reversibility' and extending the meaning of the latter to include imminence. However, the idea of imminence can alternatively - and in line with the alternative trajectory I have identified - be understood as a further determination of the philosophical meaning of the chiasm within which both reversibility and imminence play distinguishable although inter-related roles. Both readings can be supported by reconstructions of the same textual evidence. Specifically, the alternative reading would not require the claim that reversibility is always imminent - that is, continually anticipated entails that the latter term is part of the intension of Reversibility*. The relation may be synthetic (based on existential relations), not analytic (based on definition).

What, then, of Merleau-Ponty's challengingly tortured claim that reversibility is 'never realized in fact' (VI 147-8; 194)? The failure of a term to be realized is not usually part of its intension. Making it so stretches the term to the limits of its expressive capacity. This could only be justified if Reversibility* were more expressive than the ordinary usage. This statement is surely intentionally awkward: we are faced with a conundrum. I think this is 
because Merleau- Ponty is trying to express an on-going dialectic between reversibility and irreversibility, which is never finally resolved on one side or the other. No doubt this is, as Saint Aubert has argued, intended by what I am calling Reversibility ${ }^{*}$. But the problem is that including the failure of 'reversibility' (in its normal sense) within Reversibility* not only is strained, but fails to show up the tension he is trying to address, exactly because it is sublimated rather than exhibited. In contrast, treating 'reversibility' and 'imminent' as distinct and in tension - yet inter-related - allows the mutual implication and difference of the chiasm to be exhibited. We are faced with a crisis in the text - a resistance in what we read. Taking up this crisis and working with it opens up a turning point where the work of expressing the meaning of the chiasm is revealed.

So how does the alternative reading parse this - necessarily, I believe - difficult claim? We can understand it in the following way: imminence intervenes in or interrupts the process of reversibility so that the latter is never fully realized in any actual reversal. Thus in this complex statement, 'imminence' operates as a restriction on 'reversibility' within MerleauPonty's account of my two hands touching. Moreover, it is not just that any actual reversal is interrupted; the failure is systematic so that even the possibility of reversal - reversibility (in its normal sense) - is compromised. My experience of activity and passivity can never simply coincide.

Imminence - whether it is considered as part of the intension of reversibility or as a restriction on it - expresses difference as the idea of a gap between anticipation and its fulfilment. This implies the temporal character of the chiasm as a process marked by an interruption between its initiation and its completion, possible or actual. Thus I agree with Irigaray that reversibility has to be interrupted, if by that she means that the chiasm must be marked by discontinuity as well as continuity, while disagreeing with her that Merleau-Ponty fails to account for this (Irigaray, An Ethics of Sexual Difference, 180; Éthique de la différence sexuelle, 168).

Merleau-Ponty shows that imminence is critical in the passage quoted at the outset of this section: 'It is time to emphasize that it is a reversibility always imminent ...'. He goes on to develop a series of related terms, which I can only mention briefly here. It is, however, arguable that they elaborate on imminence. To say that there is an 'incessant escaping' (dérobade incessante) of my touching-touched hand expresses how it is experienced as both active and passive at the same time and yet these experiences cannot be entirely identified with one another. This expression brings out the uncanny difference between activity and passivity that arises from their being on the verge of coinciding and yet they do not - that is, they are and remain imminent to each other. The 'shift' (bougé) expresses the continuity between the two hands, even though only indeterminately because activity and passivity are unified in a blurred fashion, as when something has moved when a photograph is taken. When something is imminent, it is close - so close that it is difficult to clearly see its boundaries. Nonetheless, spreading (écart) expresses distance within continuity. The relation between my hands is spread out or stretched to its limits. This brings out how imminence implies connection over a distance. Hiatus implies the gap - even though it may be infinitesimal - in the imminent relation between the activity and passivity of my hands (VI 148; 194-5). Each term - and this is not an exhaustive list - adds a subtle but specific nuance to the uncanny combination of difference with continuity that lies at the heart of Merleau-Ponty's chiasm. ${ }^{27}$

Nonetheless, I am not arguing that we should adopt 'imminence' as the new master term containing these other terms within its intension. While I believe that Merleau-Ponty inaugurated a philosophy of imminence, its effective expression requires a plurality of distinctively nuanced terms operating as elaborations of - as well as in some tension with one another. 


\section{How the figure of a threshold illuminates the transitional status of the chiasm}

The chiasm's combination of mutual implication and difference makes its further determination difficult. If we focus primarily on what is shared between the elements of a relation considered as their identity, difference appears at best provisional as we saw in Dillon's account of 'ideal harmony'. If we were, on the contrary, to focus principally on difference and treat it as synonymous with opposition, we would lose sight of the chiasm as crossing over from one element to another. As an alternative to both of these, we have seen that when one element of a relation is imminent to another, they imply one another and yet they are also distinct. In this section I further explore the logic of imminence that MerleauPonty initiates but does not explicitly develop.

The distinctive structure of the chiasm as imminent can only be grasped once we recognize its character as ambiguous. As Adams argues, Merleau- Ponty's concept of ambiguity does not undermine his commitment to meaningfulness, as ambiguity is distinct from the meaningless or absurd and expresses the genesis of meaning (Adams, 'Merleau-Ponty and the Advent of Meaning'). Ambiguity is central to Merleau-Ponty's Phenomenology of Perception, but equally to his late work. ${ }^{28}$ For Merleau-Ponty, my two hands never coincide in a united experience, yet they 'are part of the same body' (VI 148; 194). I experience activity and passivity ambiguously, because the hand I experience as active is about to become passive and vice versa: activity and passivity are imminently related.

This feeling of irreducible ambiguity is a form of self-awareness: 'I hear myself both from within and from without' (VI 148, 194). I think Merleau- Ponty means that I become aware of myself because I am forced to combine experiences belonging to two perspectives - active and passive - both of which belong to my own body. I become aware of myself crossing over between activity and passivity: I experience the transition or metamorphosis of the one experience into the other' (VI 148, 194). This transition is the experience of the imminence of activity and passivity in relation to one another. Thus the chiasm operates as an uncanny awareness of a crossing over between one perspective and another. While Merleau-Ponty's account of the awareness of transition is underdeveloped, it is crucial for establishing that the chiasm is not simply a 'switching' or flipping from one side to another. No doubt the chiasm's transitional status can be included within Reversibility*. However, this strategy does not draw sufficient attention to the experience of transition and our awareness of it. In contrast, drawing out the distinctive implication of imminence allows the transitional character of the chiasm to be seen.

I now introduce the figure of a threshold as heuristic for the visualization and further exploration of the imminent structure of the chiasm. Although this not an idea Merleau-Ponty explicitly introduces, it is in the spirit of his insights into the chiasm as a crossing and transition. Moreover, it takes up the potential of an idea introduced in a Working Note from November 1960, namely that the chiasm - and, at the same time, reversibility - qualifies as 'frontier surface' (surface frontière) (VI 263; 317; see also VI 145; 190-1). The figure of a threshold allows us to examine transitions - or possible transitions - between multiple perspectives. At a threshold, one thing is on the verge of becoming another - it is imminent and as a result the transition can be seen as a process, rather than as already completed. The figure of the threshold brings the imminence of the chiasm to the fore and thus allows the work necessary for the expression of the latter to become visible.

A threshold joins together two - or more - elements that are nonetheless different. A threshold at the entrance to a room - to take the most simple of cases - can be seen as belonging to this room or to the adjacent room, but in fact it belongs to both and neither. When I stand at the threshold, my being in one space or another is imminent and not yet determined with respect to one room or the other. It is in the nature of a threshold that it is 
intermediary, indeterminate and ambiguously in-between because it is transitional between one determination and another.

The threshold both joins and differentiates and thus helps us see how the elements of a relation can be both irreducible to and yet mutually implied by one another. This can only be the case because the threshold itself is ambiguous, that is, it is both irreducible to and implicated in the elements on either side of it. If a threshold amounted to nothing other than an alternation or 'switching' between terms, there would be a merely indifferent relation amounting to no genuine relation at all. The threshold has to be distinguishable from the elements it conjoins, even though in order to operate as a threshold it cannot be pinned down as 'a thing' or 'a place' and remains indeterminate.

Think of a border, a particular species of threshold. A border separates two countries, but it is also where we can move from one to the other. Rivers, natural features that are both boundaries and means of transportation from one place to another, traditionally have served as borders. Moreover, an actual border - rather than one marked on a map - usually has elements of indeterminacy about it. Where exactly do we cross the border from Northern Ireland into the Republic of Ireland? No doubt there is a technical determination of the 'exact' position of the border in legal documents and border police will operate with an understanding of where their jurisdiction begins and ends. However, the lived experience of a border is much more complex, an example of which is the ambiguous cultural identity of many border towns. Wordsworth captures the ambiguity of another type of natural border - a range of mountains - in poetic form, when he recalls how, still on the way - in his own mind - to crossing the Alps he is informed by a Savoyard peasant that he has already crossed them (Wordsworth, The Prelude, Book 6, 557-91).

Given the examples considered so far, we might conclude that a threshold is necessarily spatial. This would limit its explanatory power in respect of the chiasm. The specific interruption that arises for an active-passive body may be temporal. Indeed, the meaning of 'imminence' is that something is 'about to happen'. Moreover, I have argued that one of the principal features of the chiasm is that it operates as a process. ${ }^{29}$ But this is also true of a threshold. One striking example of a temporal threshold is the present, which is continuous with the past and the future and yet irreducible to either. ${ }^{30}$ We should not conclude, however, that the chiasm is temporal rather than spatial, for what is under consideration is embodied being, which must always stand in some relation to spatiality. ${ }^{31}$

The figure of a threshold also brings out how the transitional status of the chiasm is compatible with the possibility that any actual transition may break down. Irigaray's alternative version of the chiasm is explicitly presented as a threshold (un seuil) (An Ethics of Sexual Difference, 18; Éthique de la différence sexuelle, 24), which she argues is always open (An Ethics of Sexual Difference, 11, 70, 106-7, 118, 141; Éthique de la différence sexuelle, 18-9, 72-3, 104, 114-5, 134). I would suggest, however, that this is only one half of the story, for because the threshold is where difference arises, separation could also occur. Admittedly, if a threshold is a crossing - or, more precisely, a possible crossing - as I am arguing, then it must at least in principle be possible that the threshold is open. What cannot be ruled out, however, is that the threshold - or border - may in fact be closed. The logic of Irigaray's own argument seems to entail that a threshold can only secure sexual difference if it is not necessarily open. Perhaps this is why Irigaray says on a number of occasions that the threshold is 'partway open' (An Ethics of Sexual Difference, 149, 18; Éthique de la différence sexuelle, 141, 24). But it is striking the extent to which she emphasizes openness and does not equally explore the separation that could arise at a threshold, especially given the emphasis she puts on interruption. There appears to be little argumentative distance between saying that the threshold is always open and saying that it is necessarily open. And if this were the case, then the difference to which Irigaray is committed is under threat because the transition between one element and another must 
occur across the open threshold. Despite his saying that reversibility never happens in fact Merleau-Ponty also fails to adequately address the way in which not only difference but also separation can arise at a chiasm.

The threshold, as I understand it, both joins and divides and thus allows that which lies on either side to be both continuous and discontinuous at the same time. It can do so only insofar as it is indeterminate and ambiguous. Thus the sense of threshold I am proposing is not that of a stable point - a 'threshold bar' - between two related spaces. This is in contrast to Heidegger, for whom the threshold (die Schwelle) is dependable, enduring, hard and settled (Heidegger, Poetry, Language, Thought, 204; Unterwegs zur Sprache, 24). While thresholds can be ossified, I am arguing for their indeterminacy prior - though not necessarily antagonistic - to stabilization. That Irigaray's view of the threshold is so far from Heidegger's is consistent with its ambiguous status. The deeper significance of the threshold as lying in-between is that it is a crossing over where an exchange, a transition or transfer is possible, but which - just because it is characterized by imminence or the 'not yet' - may also be blocked and thus become ossified.

We can better grasp the imminent structure of Merleau-Ponty's chiasm and the force of the examples he provides with the help of the figure of a threshold. My touching-touched hand hovers on the threshold between activity and passivity (see Hughes, 'A Passivity Prior to Passive and Active'). Similarly, the meaning of a piece of music arises at the threshold of our auditory perception in an idea that is dependent on and yet in excess of its performance. Likewise, my consciousness of the forest requires that I am able to give myself over to the forest so that my attention is taken up with and, even, taken over by it and yet it is still my consciousness of the forest: my experience of one perspective imminently implies the other. The same is true for my consciousness of the landscape and of the blue of the sky. My absorption in something requires transitions between consciousness and its objects, where I am neither identical nor opposed to the object of my reflection. This exchange between mind and world operates through existential relations, which - like a threshold - require both mutual implication and difference within a logic of imminence. ${ }^{32}$

\section{Footnotes}

1. A rare but influential voice denying this is Barbaras, 'Le problème du chiasme', 15, who insists that 'chiasm' is not the key concept.

2. This idea was already introduced as the 'intersensory' in the Phenomenology of Perception.

3. Merleau-Ponty, Phenomenology of Perception, 302; Phénoménologie de la Perception, 299-300 compares relations between elements within perception to the reciprocal relations between the motivating and the motivated'. These, in contrast to causal relations, are linked through meanings.

4. $\quad \mathrm{VI}=$ Merleau-Ponty, The Visible and the Invisible; Le visible et l'invisible.

5. Merleau-Ponty's account of the relation between the sensory and the ideal is clearly influenced by Husserl, 'The Origin of Geometry'.

6. The relation between identity and difference is a major topic within the history of philosophy, for instance, in German Idealism. More recently, the philosophical importance of difference has most overtly been taken up within continental philosophy, for instance, in Derrida's (Margins of Philosophy; Marges de la philosophie) notion of différance. The idea of difference also plays a role in analytical philosophy, for instance, in the idea of the incommensurability of paradigms (Kuhn, The Structure of Scientific Revolutions) and in the view that 'second-personal authority' is irreducible to the third person perspective (Darwall, The Second-person Standpoint, 9). 
7. Saint Aubert, Le Scénario Cartésien, 167 points out that 'chiasm' (chiasma) was already used in 'L'homme et l'adversité' (1951). Chiasma is also used in the Resumé du cours for 1952-1953 and in the Preface to Signs (1960).

8. Saint Aubert, Du Lien des Êtres aux Éléments de l'Être argues that Merleau-Ponty's 'flesh' is characterized by encroachment. Saint Aubert, Le Scénario Cartésien attributes the same feature to the chiasm.

9. Saint Aubert, Du Lien des Êtres aux Éléments de Être, 170 remarks that flesh is the body's 'completion and exceeding'. Although Heidegger Being and Time; Sein und Zeit, (particularly the discussion of mood) arguably presupposes embodiment, the latter is not taken up as a theme. Saint Aubert, Du Lien des Êtres aux Éléments de Être, 174 argues that Merleau-Ponty's notion of 'flesh' should not be taken as a 'translation' of Husserl's Leib as the latter arises from a process of abstraction alien to Merleau-Ponty.

10. Johnson in Merleau-Ponty $1993,43-4$ claims that this is 'the purest expression of reversibility'.

11. Johnson quotes Merleau-Ponty, Sense and Non-sense, 17; Sens et non-sens, 30, who quotes Cézanne.

12. The idea of the touching touched was already explored in Husserl, Ideas Pertaining to a Pure Phenomenology and to a Phenomenological Philosophy, 155; Hu IV 148.

13. Recorded by Naxos and Hyperion, respectively.

14. Gould playing Bach's 'Prelude and Fugue in A' from The Well Tempered Clavier is available on Youtube: http://www.wqxr.org/\#!/story/239790-glenn-goulds-five-most-watched-youtube-videos/. (accessed: 18th May, 2016)

15. The chiasm qualifies as an exchange (échange) for Merleau-Ponty, but this does not preclude difference (VI 143; 188). See also his addition on 145; 190: 'the exchange of words is exactly the differentiation of which the thought is the integral'.

16. For Carman (Merleau-Ponty, 124-6) Merleau-Ponty's use of chiasm is continuous with the rhetorical sense of the term as parallel and reciprocal. Saint Aubert, Le Scénario Cartésien, 172 suggests that Valery - who greatly influenced Merleau-Ponty's idea of the chiasm-went beyond the classical rhetorical sense of the term.

17. Interpreters who treat reversibility as if it were equivalent to the chiasm include Carman, MerleauPonty, 124; Carbone, The Thinking of the Sensible Merleau-Ponty's A-Philosophy, 26; Johnson and Smith, Ontology and Alterity in Merleau-Ponty, 1993, 43-4; and Adams, 'Merleau-Ponty and the Advent of Meaning'. Low, Merleau-Ponty's Last Vision, 33-4 argues that there is a series of chiasms, which are representative of his 'reversibility thesis' (p. 57). See also Morris, 'The Enigma of Reversibility and the Genesis of Sense in Merleau-Ponty', who understands reversibility as chirality or 'handedness' entailing difference.

18. See also Levinas, Totality and Infinity, 206-7; Totalité et Infinité, 181-2.

19. See for instance, Levinas, 'Language and Proximity', 116; En decouvrant l'existence avec Husserl et Heidegger, 225 where he refers to his own ethics as 'a reversal' (un retournement).

20. See Bernasconi, 'One-way Traffic', 74-5.

21. 'The one-way movement would be reversed (s'invertirait) and become a reciprocity.'

22. See Hass 101, 96-7 and 99-100, respectively, for a response to each of these objections.

23. Johnson comments that if 'reversibility' is understood logically, it implies 'the bi-conditional' and, thus, symmetry. He argues that the term can, however, also be understood dialectically or aesthetically (as mirror images) and in both cases difference is implied. See Johnson and Smith, 
Ontology and Alterity in Merleau-Ponty, xxvii-xxviii. Adams, 'Merleau-Ponty and the Advent of Meaning' argues that Merleau-Ponty goes beyond an earlier idea of reciprocal exchange to a later idea of reversibility as ambiguous.

24. See Saint Aubert, Le Scénario Cartésien, 30-47 on Merleau-Ponty's idea of 'the clarity of confusion'.

25. Saint Aubert (Du Lien des Êtres aux Éléments de l'Être Section A) shows how 'flesh' already had well-established senses (including within Christian theology) but argues that Merleau-Ponty does not simply adopt any of these senses (158).

26. Flesh is Merleau-Ponty's development of what Heidegger (Being and Time; Sein und Zeit) calls 'Being' (Sein).

27. See, for instance, Lawlor, The Implications of Immanence, 113 and Toadvine, Merleau-Ponty's Philosophy of Nature, 125 on écart. Doyle, 'Bodies Inside/Out' develops Merleau-Ponty's account of the hiatus as making possible a difference within the self.

28. For discussions of the role of ambiguity in Merleau-Ponty's thinking, see, for instance, Dreyfus and Todes, 'The Three Worlds of Merleau-Ponty', Dillon, 'Merleau-Ponty and the Reversibility Thesis', Weiss, 'Ambiguity, absurdity and reversibility', Lawlor, 'The end of phenomenology', Adams, 'Merleau-Ponty and the advent of meaning'. But see also Sapontzis, 'A Note on MerleauPonty's "Ambiguity"' who argues against attributing a 'philosophy of ambiguity' to Merleau-Ponty.

29. See Barbaras, The Being of the Phenomenon, 224; De l'être du phénomène, 257: 'The truth of the chiasm truly resides in temporality'. See also, 204; 235. See also Mazis, 'Merleau-Ponty and the "Backward Flow" of Time' on reversibility and temporality.

30. See Husserl, On the Phenomenology of the Consciousness of Internal Time, Section 11, Hu 2931 on retention and On the Phenomenology of the Consciousness of Internal Time, Section 24, Hu 52-3 on protention. See Barbaras, The Being of the Phenomenon, 217-26; De l'être du phénomène, 250-60.

31. See Merleau-Ponty, Phenomenology of Perception, 115-6; Phénoménologie de la Perception, 117 on the distinction between 'spatiality' as generative and 'space' conceived as points or positions.

32. I would like to thank a number of people who have commented on my paper at different stages of its evolution: James Corby, Sebastian Gardner, Beatrice Han-Pile, Irene McMullin, Stephen Mulhall and Pauline Phemister. I have, additionally, benefited from a number of discussions, including those arising from the presentation of earlier versions of this paper at the Universities of Essex, Sussex and Warwick, as well as at the 2015 Annual Conference of the Society of Women in Philosophy at the University of Essex. Finally, I am grateful for the very helpful comments of two anonymous reviewers, as well as those of the Editor of the BJHP.

\section{References}

Adams, H. 'Merleau-Ponty and the Advent of Meaning: From Consummate Reciprocity to Ambiguous Reversibility'. Continental Philosophy Review 34 (2001): 203-224.

Barbaras, R. De l'être du phénomène: Sur l'ontologie de Merleau-Ponty. Grenoble: Jérôme Millon, 1991.

Barbaras, R. 'Le problème du chiasme'. Studia Phaenomenologica III, no. 3-4 (2003): 15-20.

Barbaras, R. The Being of the Phenomenon. Bloomington: Indiana University Press, 2004.

Bernasconi, R. 'One-way Traffic: The Ontology of Decolonization and its Ethics'. In Ontology and Alterity in Merleau-Ponty, edited by G. A. Johnson and M. B. Smith, 67-80. Evanston, IL: Northwestern University Press, 1990.

Carbone, M. The Thinking of the Sensible Merleau-Ponty's A-Philosophy. Evanston, IL: Northwestern University, 2004.

Carman, T. Merleau-Ponty. London: Routledge, 2008.

Darwall, S. The Second-person Standpoint. Cambridge: Harvard University Press, 2009. 
Derrida, J. Marges de la philosophie. Paris: Minuit, 1972.

Derrida, J. Margins of Philosophy. Translated by Alan Bass. Chicago, IL: University of Chicago Press, 1982.

Dillon, M. C. 'Merleau-Ponty and the Reversibility Thesis'. Man and World 16 (1983): 365-88.

Dillon, M. C. Merleau-Ponty's Ontology. 2nd ed. Evanston, IL: Northwestern University Press, 1997.

Doyle, L. 'Bodies Inside/Out: Violation and Resistance from the Prison Cell to The Bluest Eye'. In Feminist Interpretations of Maurice Merleau-Ponty, edited by D. Olkowski and G. Weiss, 183-208. PA: University of Pennsylvania Press, 2006.

Dreyfus, H., and S. J. Todes. 'The Three Worlds of Merleau-Ponty'. Philosophy and Phenomenological Research 22, no. 4 (1962): 559-65.

Hass, L. 'Sense and Alterity. Rereading Merleau-Ponty's Reversibility Thesis'. In Merleau- Ponty, Interiority and Exteriority, Psychic Life and the World, edited by D. Olkowski and J. Morley, 91105. Albany: State University of New York Press, 1999.

Hass, L. Merleau-Ponty's Philosophy. Bloomington: Indiana University Press, 2008.

Heidegger, M. Poetry, Language, Thought. Translated by A. Hofstadter. New York: Harper \& Row, 1975.

Heidegger, M. Being and Time. Translated by J. Macquarrie and E. Robinson. Oxford: Basil Blackwell, 1978.

Heidegger, M. Unterwegs zur Sprache. Translated by Hrsg. Von Friedrich-Wilhelm v. Hermann. Frankfurt am Main: Klostermann, 1985.

Heidegger, M. Sein und Zeit. Tübingen: Max Niemeyer Verlag, 1986.

Hughes, F. 'A Passivity Prior to Passive and Active: Merleau-Ponty's Re-reading of the Freudian Unconscious and Looking at Lascaux'. Mind 122 (2013): 419-450.

Husserl, E. 'The Origin of Geometry'. In The Crisis of the European Sciences and Transcendental Phenomenology: An Introduction to Phenomenological Philosophy, edited by Husserl, 353-378. Evanston: Northwestern, 1970. [Husserliana VI]

Husserl, E. Ideas Pertaining to a Pure Phenomenology and to a Phenomenological PhilosophySecond Book: Studies in the Phenomenology of Constitution. Translated by R. Rojcewicz and A. Schuwer. Dordrecht: Kluwer, 1989. [Husserliana IV]

Husserl, E. On the Phenomenology of the Consciousness of Internal Time. The Hague: Martinus Nijhoff, 1992. [Husserliana X]

Irigaray, L. Éthique de la différence sexuelle. Paris: Minuit, 1984.

Irigaray, L. An Ethics of Sexual Difference. Translated by C. Burke and G. C. Gill. Ithaca, NY: Cornell University Press, 1993.

Johnson, G. A., and M. B. Smith, eds. Ontology and Alterity in Merleau-Ponty. Evanston, IL: Northwestern University Press, 1990.

Kuhn, T. The Structure of Scientific Revolutions. Chicago, IL: University of Chicago Press, 1962.

Lawlor, L. 'The end of phenomenology: Expressionism in Deleuze and Merleau-Ponty'. Continental Philosophy Review 31 (1998): 15-34.

Lawlor, L. The Implications of Immanence: Towards a New Concept of Life. New York: Fordham University Press, 2006.

Levinas, E. 'Le signification et le sens'. Revue de Metaphysique et de Morale 69, no. 2 (1964): 12556.

Levinas, E. Totality and Infinity. Translated by A. Lingis. Pittsburgh: Duquesne University Press, 1969.

Levinas, E. Totalité et Infinité. The Hague: Martinus Nijhoff, 1984 (1961).

Levinas, E. 'Meaning and Sense'. In Collected Philosophical Papers. Translated by A. Lingis, 75-107. Dordrecht: Martinus Nijhoff, 1987.

Levinas, E. 'Language and Proximity'. In Collected Philosophical Papers. Translated by A. Lingis, 75107. Dordrecht: Martinus Nijhoff, 1987.

Levinas, E. En découvrant l'existence avec Husserl et Heidegger. Paris: Vrin, 1994.

Low, D. Merleau-Ponty's Last Vision. Evanston, IL: Northwestern, 2000.

Mazis, G. 'Merleau-Ponty and the "Backward Flow" of Time: The Reversibility of Temporality and the Temporality of Reversibility'. In Merleau-Ponty, Hermeneutics and Postmodernism, edited by T. W. Busch and S. Gallagher, 53-68. Albany: State University of New York Press, 1992.

McCarthy, C. The Road. London: Picador, 2010.

Merleau-Ponty, M. Phénoménologie de la Perception. Paris: Gallimard, 1945.

Merleau-Ponty, M. Signes. Paris: Gallimard, 1960.

Merleau-Ponty, M. Signs. Translated by R. C. McCleary. Evanston, IL: Northwestern University Press, 1964.

Merleau-Ponty, M. Le visible et l'invisible. Paris: Gallimard, 1964. [=VI] 
Merleau-Ponty, M. The Primacy of Perception. Evanston: Northwestern University Press, 1964.

Merleau-Ponty, M. L'oeil et l'esprit. Paris: Gallimard, 1964.

Merleau-Ponty, M. Sense and Non-sense. Evanston: Northwestern University Press, 1964.

Merleau-Ponty, M. Sens et non-sens. Paris: Nagel, 1966.

Merleau-Ponty, M. The Visible and the Invisible. Edited by Claude Lefort, Translated by A. Lingis. Evanston, IL: Northwestern University Press, 1968. [=VI]

Merleau-Ponty, M. La Prose du Monde. Evanston, IL: Northwestern University Press, 1969.

Merleau-Ponty, M. The Prose of the World. Paris: Gallimard, 1973.

Merleau-Ponty, M. The Merleau-Ponty Aesthetics Reader. Edited by Galen A. Johnson. Evanston, IL: Northwestern University Press, 1993.

Merleau-Ponty, M. Phenomenology of Perception. Translated by Colin Smith. Abingdon: Routledge, 2002.

Morris, D. 'The Enigma of Reversibility and the Genesis of Sense in Merleau-Ponty'. Continental Philosophy Review 43 (2010): 141-65.

Proust, M. À la recherche du temps perdu I. Paris: Gallimard, 1987.

Proust, M. In Search of Lost Time. Vol. 1 Translated by C.K. Scott Moncrieff and T. Kilmartin. Revised by D.J. Enright. London: Vintage, 1996.

Olkowski, D., and G. Weiss. Feminist Interpretations of Maurice Merleau-Ponty. Pennsylvania: University of Pennsylvania Press, 2006.

Saint Aubert, E. Du Lien des Êtres aux Éléments de l'Être. Paris: Vrin, 2004.

Saint Aubert, E. Le Scénario Cartésien. Paris: Vrin, 2005.

Saint Aubert, E. Être et Chair. Paris: Vrin, 2013.

Sapontzis, S.F. 'A Note on Merleau-Ponty's "Ambiguity"'. Philosophy and Phenomenological Research 38, no. 4 (1978): 538-43.

Toadvine, T. Merleau-Ponty's Philosophy of Nature. Evanston, IL: Northwestern University Press, 2009.

Weiss, G. 'Ambiguity, Absurdity and Reversibility: Indeterminacy in De Beauvoir, Camus and MerleauPonty'. Journal of French and Francophone Philosophy 5, no. 1 (1993): 71-83.

Wordsworth, W. The Prelude. 1805. http://self.gutenberg.org/eBooks/WPLBN0000694384- ThePrelude-of-1805-in-Thirteen-Books-by-Wordsworth-William.aspx 